Drink. Water Eng. Sci. Discuss., https://doi.org/10.5194/dwes-2017-21

Manuscript under review for journal Drink. Water Eng. Sci.

Discussion started: 8 June 2017

(c) Author(s) 2017. CC BY 3.0 License.

\title{
Numerical scour modeling around parallel spur dikes in FLOW-3D
}

\author{
Hanif Pourshahbaz ${ }^{1}$, Saeed Abbasi ${ }^{1}$, Poorya Taghvaei ${ }^{2}$ \\ 1. Department of Civil Engineering, University of Zanjan, Zanjan, Iran \\ 2. Department of Civil Engineering, Semnan University, Semnan, Iran
}

5 Correspondence to: Poorya Taghvaei (Pooryataghvaei@yahoo.com)

\begin{abstract}
Spur dikes are some structures which are built in the flow path with the aim of changing flow characteristics in order to bed and bank protection in rivers. These sudden changes in properties caused by the existence of spur dikes, produces erosion and sedimentation around them. In this paper, effects of series of parallel spur dikes have been investigated numerically. For this purpose, by using experimental and numerical research results from technical literatures, the numerical model conducted in FLOW-3D commercial software and the data were compared with experimental and SSIIM results. The results showed that Froude number and the ratio of $\mathrm{U} / \mathrm{U}_{\mathrm{cr}}$ affect the accuracy of the models. As a result, by discharge increasing, FLOW-3D models need to be calibrated again. Also, by using a calibrated FLOW-3D model, calculation accuracy of the scour depth at the bottom of the spur dikes becomes better and the accuracy level in the modeling of the surface morphology improves 7 percent more than SSIIM software in the bottom of the first spur dike, more than 80 percent at the bottom of the second spur dike and approximately 40 percent at the bottom of the last spur dike.
\end{abstract}

Keywords: spur dike, scour, sedimentation, numerical simulation, FLOW-3D, Van Rijn

\section{Introduction}

Spur dikes are known as structures that are built in the flow path and they are extended from adjacent beach to the center of flow with the aim of reducing coastal erosion by diverting the flow path (Kuhnle et al.,2002). Also, these structures will be used for the purpose of aquatic habit (Klingeman et al., 1984) or coast recreation (Chang et al., 2013). Three-dimensional flow patterns will be changed when flumming structures are placed in channel surface through vortex current development. In spur dikes cases, flow separated at upstream of spur dikes and went to levees and created vortexes move to the downstream which finally causes local deposition surface scouring around the structure. In the usage of spur dikes for any purposes, maximum scour depth and scour around spur dikes are so important as can be seen in many researches such as:(Ahmad, 1951,1953), (Garde et al.,1961), (Gill, 1972), (Richardson et al., 1975), (Rajaratnam et al., 1983), (Shields et al., 1995), (Kuhnle et al., 1999), (Kothyari et al., 2001), (Barbhuiya et al., 2004), (Kang et al., 2011), this depth is investigated. In many researches, spur dikes are studied individually. Since these structures are mainly built in groups and the flow characteristic would vary in peak and between spur dikes, researchers such as (Chang et al., 2013) and (Karami et al., 2014) investigated the scour depth in groups of spur dikes. Due to the greater interaction between flow and sediment and revealing 
Drink. Water Eng. Sci. Discuss., https://doi.org/10.5194/dwes-2017-21

Manuscript under review for journal Drink. Water Eng. Sci.

Discussion started: 8 June 2017

(c) Author(s) 2017. CC BY 3.0 License.

turbulent flow in group of spur dikes, exact scour depth forecasting needs consideration of flow turbulence in scouring hole (Mendoza, 1993).

Computational fluid dynamic (CFD) is used in numerical models (Acharya et al., 2013) and in recent years various commercial models such as FLOW-3D, SSIIM and Fluent are developed. Modelling of flow and sediment transport around

5 spur dikes needs at least solving two-dimensional hydrodynamics equations and sediment model simultaneously (Duan et al. 2006, Kuhnle et al. 2008).

In this research, three-dimensional flow is used for scour modelling around impermeable parallel series of non-submerged vertical spur dikes. This type of modelling is used in enormous studies such as (An et al., 2015), (Li et al., 2016) and (Shamohamadi et al., 2016) for scour and sediment transport module which is recently added to FLOW-3D. In order to

10 validate numerical simulation, experimental and numerical results presented by (Karami et al., 2014) are compared with FLOW-3D results.

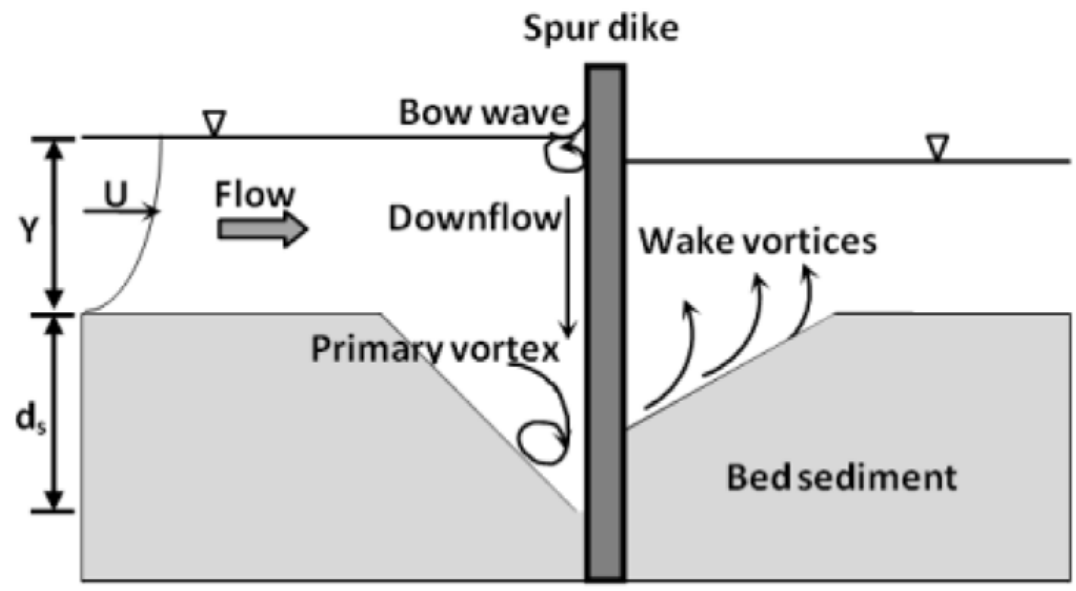

Figure 1: Schematic diagram of flow pattern and scouring around spur dike (Karami et al., 2014)

\section{Materials and Methods:}

\section{Governing equations in hydrodynamic model}

Fluid motion equations include continuity and momentum equations. Continuity equation and momentum equations in Cartesian coordinate are presented in equations 1 to 4 . Equation 5 represents the volume of fluid equation:

$V_{F} \frac{\partial \rho}{\partial t}+\frac{\partial}{\partial x}\left(\rho u A_{x}\right)+R \frac{\partial}{\partial y}\left(\rho v A_{y}\right)+\frac{\partial}{\partial z}\left(\rho w A_{z}\right)=R_{S O R}$

$\frac{\partial u}{\partial t}+\frac{1}{V_{F}}\left(u A_{x} \frac{\partial u}{\partial x}+v A_{y} R \frac{\partial u}{\partial y}+w A_{z} \frac{\partial u}{\partial z}\right)-\xi \frac{A_{y} v^{2}}{x V_{F}}=-\frac{1}{\rho} \frac{\partial \rho}{\partial x}+G_{x}+f_{x}$

$\frac{\partial v}{\partial t}+\frac{1}{V_{F}}\left(u A_{x} \frac{\partial v}{\partial x}+v A_{y} R \frac{\partial v}{\partial y}+w A_{z} \frac{\partial v}{\partial z}\right)-\xi \frac{A_{y} u v}{x V_{F}}=-\frac{R}{\rho} \frac{\partial \rho}{\partial y}+G_{y}+f_{y}$ 
Drink. Water Eng. Sci. Discuss., https://doi.org/10.5194/dwes-2017-21

Manuscript under review for journal Drink. Water Eng. Sci.

Discussion started: 8 June 2017

(c) Author(s) 2017. CC BY 3.0 License.

$\frac{\partial w}{\partial t}+\frac{1}{V_{F}}\left(u A_{x} \frac{\partial w}{\partial x}+v A_{y} R \frac{\partial w}{\partial y}+w A_{z} \frac{\partial w}{\partial z}\right)=-\frac{1}{\rho} \frac{\partial \rho}{\partial z}+G_{z}+f_{z}-b_{z}$

$V_{F} \frac{\partial F}{\partial t}+\nabla \cdot(A U F)=0$

In these equations, $V_{F}=$ open volume ratio to flow, $\rho=$ fluid density, $(u, v, w)=$ velocity components in $(x, y, z), R_{S O R}=$ source function, $\left(A_{x}, A_{y}, A_{z}\right)=$ fractional areas, $\left(G_{x}, G_{y}, G_{z}\right)=$ gravitational force, $\left(f_{x}, f_{y}, f_{z}\right)=$ viscosity acceleration, $\left(b_{x}, b_{y}, b_{z}\right)=$ flow losses in porous media in $(x, y, z)$ directions, respectively. The final part of 2 to 4 equations show mass injection in zero velocity. In relation $5, \mathrm{~A}=$ average of area flow, $\mathrm{U}=$ average velocity in $(x, y, z)$ direction and $\mathrm{F}$ is volume fluid

5 function. When the cell is full by the fluid, the F value is 1 and when it is empty it is 0 . InFLOW-3D, two methods are used for simulation called Volume of Fluid (VOF) that is used to show the behaviour of fluid at the free surface and the Fractional Area-Volume Obstacle Representation (FAVOR) method, a program used for surfaces modelling and rigid volumes such as geometric borders.

\section{Governing equations in sediment transport model}

10 Suspended load and bed load is evaluated separately for sedimentary computing section. Suspended sediment load is acquired by solving the transient convection-diffusion equation (equation 6 ).

$\frac{\partial c}{\partial \mathrm{t}}+U_{i} \frac{\partial c}{\partial x_{i}}+W \frac{\partial c}{\partial z}=\frac{\partial}{\partial x_{i}}\left(\Gamma \frac{\partial c}{\partial x_{i}}\right)$

Where $\mathrm{U}=$ Reynolds-average water velocity, $\mathrm{W}=$ fall velocity of sediment, $\mathrm{x}=$ general space dimension, $\mathrm{z}=$ dimension inthe vertical direction, $\Gamma=$ diffusion coefficient. The diffusion coefficient is equal to flow eddy viscosity which is calculated by thek $-\varepsilon$ model. This equation describes sediment transport which includes the effect of the turbulence on deceleration

15 sediment particles settlement. This equation is solved by control volume method in FLOW-3D model on every cell except those are close to the bed. In order to calculate concentration and surface adjacent load, four models, namely Van Rijn equation and Nielsen equation, Meyer-Peter \& Muller equation are developed. In this article, Van Rijn equation model is used in order to compare FLOW-3D with SSIIM model in both models. In surface cells, sediment concentration and bed load are calculated by (Van Rijn, 1987) equation respectively, which are presented in equations 6 and 7:

$c_{\text {bed }}=0.015 * \frac{d^{0.3}\left(\frac{\tau-\tau_{c}}{\tau_{c}}\right)^{1.5}}{g\left(\frac{\rho_{s}-\rho_{w}}{\rho_{w} \vartheta^{2}}\right)^{0.1}}$

20 In which $\mathrm{d}=$ diameter of sediment particle, $\tau=$ bed shear stress, $\tau_{\mathrm{c}}=$ critical shear stress for sediment particle motion according to Shields diagram, $\rho_{\mathrm{S}}$ and $\rho_{\mathrm{W}}=$ respectively, water density and sediment particle density, $\vartheta=$ Kinematic viscosity of water and $\mathrm{g}=$ gravitational acceleration. 
Drink. Water Eng. Sci. Discuss., https://doi.org/10.5194/dwes-2017-21

Manuscript under review for journal Drink. Water Eng. Sci.

Discussion started: 8 June 2017

(c) Author(s) 2017. CC BY 3.0 License.

$\frac{q_{b}}{d^{1.5} \sqrt{\frac{\rho_{s}-\rho_{w}}{\rho_{w}} g}}=0.1 * \frac{\left(\frac{\tau-\tau_{c}}{\tau_{c}}\right)^{1.5}}{d^{0.3}\left(\frac{\rho_{s}-\rho_{w}}{\rho_{w} \vartheta^{2}}\right)^{0.1}}$

Where $q_{b}$ is indication for bed load sediment particle.

\section{Experimental model}

This paper is based on Karami et al (2014) work and their work is utilized to find how the Flow-3D could model a scouring phenomenon. They constructed a rectangular $14 \mathrm{~m}$ long flume, with $1 \mathrm{~m}$ width and $1 \mathrm{~m}$ depth in the laboratory of the

5 Amirkabir University of Technology. Three non-submerged, impermeable $25 \mathrm{~cm}$ length spur dikes were perpendicularly installed in channel. The first dike installed at a distance of 6.16 meters from the beginning of the channel and the distance between them selected twice the length. The input current is kept constant at $15 \mathrm{~cm}$ depth. They covered the flume with $0.35 \mathrm{~m}$ thickness uniform sediment $\left(\sigma_{\mathrm{g}}<1.4\right)$, median size $\left(\mathrm{d}_{50}\right) 0.91 \mathrm{~mm}$, specific gravity $\left(\mathrm{s}_{\mathrm{s}}\right) 2.65$ and standard deviation $\left(\sigma_{\mathrm{g}}\right)$ 1.38.Velocity and surface changes profile around the spur dikes was measured with ADV and LBP respectively. In table

101 details and results of their experiment has expressed which is used to validate the numerical model where $\mathrm{Q}=$ tested discharge in terms of cubic meters per second, $\mathrm{Y}=$ flow depth in terms of meter, $\mathrm{U}=$ flow velocity in term of meter per second, $\mathrm{U} / \mathrm{U}_{\mathrm{cr}}=$ flow rate to the critical Shields velocity Ratio, $\mathrm{Fr}=$ Froude number, ds 1 and ds 2 and ds $3=$ scour depth in the first, second and third spur dike, correspondingly and $\mathrm{V}=$ volume of eroded sediment in cubic meters.

Table 1: details and results of (Karami et al., 2014) experimental models

\begin{tabular}{llllllllll}
\hline \hline $\begin{array}{l}\text { Test } \\
\text { NO. }\end{array}$ & $\mathbf{Q}(\mathbf{m} 3 / \mathbf{s})$ & $\mathbf{Y ~ ( m )}$ & $\mathbf{U}(\mathbf{m} / \mathbf{s})$ & $\mathbf{U} / \mathbf{U c r}$ & $\mathbf{F r}$ & $\mathbf{d s 1}$ & $\mathbf{d s 2}$ & $\mathbf{d s 3}$ & $\mathbf{V}(\mathbf{m 3})$ \\
\hline \hline E1 & 0.035 & 0.15 & 0.233 & 0.65 & 0.19 & 0.156 & 0 & 0.026 & 0.0165 \\
E2 & 0.046 & 0.15 & 0.307 & 0.85 & 0.25 & 0.225 & 0.029 & 0.072 & 0.0668 \\
\hline \hline
\end{tabular}

\section{Description of the numerical model}

A numerical model with the characteristics of the mentioned experiments in the previous section was utilized in FLOW-3D. Units were selected as SI, the temperature in Celsius degree and water is considered as incompressible fluid. Critical Shields number was considered according to 0.91-millimeter diameter, gravitational acceleration equals to 9.807 meters per second squared, sediment particle density 2650 kilogram per cubic meter and Kinematic viscosity 10-6. Using these data and

20 Shields equation, the shields number evaluated equal to 0.033 . Richardson-Zaki coefficient controls drag impression on sediment particle settlement when the flow is concentrated. The value 1 of this coefficient was applied equal to 1 In order to unify calculation for comparing FLOW-3D and SSIIM in this modeling, $\mathrm{k}-\varepsilon$ turbulence model with the development of Renormalized group (RNG) is utilized. RNG model has been obtained by the development and expansion of standard model 
Drink. Water Eng. Sci. Discuss., https://doi.org/10.5194/dwes-2017-21

Manuscript under review for journal Drink. Water Eng. Sci.

Discussion started: 8 June 2017

(c) Author(s) 2017. CC BY 3.0 License.

based on Renormalized Group (RNG). Suspended sediment particle diffusion, is defined by two coefficients, molecular diffusion and turbulent coefficient. Turbulent diffusion coefficient is reverse of Schmidt number and approximately is equal to 1 . Sediment surface roughness is defined by the ratio of $\frac{\text { bed roughness }}{d_{50}} \cdot d_{50}$ is calculated at each time step for each sediment cell. The value of this coefficient was evaluated equal to 5.014. Particles angle of repose shows the most rely angle of the 5 bed which is usually between 30 to 40 degrees and is useful to correct the influence of the slope in critical Shields parameter. In this paper, this angle is considered equal to 30 degrees. Bed load coefficient, controls the bed load transport rate when the speed is faster than critical speed. According to (Van Rijn, 1987) equations, this value should be1. Entrainment coefficient controls scour rate. This empirical coefficient is used with the aim of comparing the rate of deposition and calibration of the model with experimental data. Default value of this coefficient was considered 0.018 according to (Mastbergen et al., 2003)

10 data. This coefficient depreciates in model by zero value. The value of this coefficient was obtained 0.036 by trial and error method according to Table 2 and applied in the models.

Table 2: Entrainment coefficient Sensitivity analyses

\begin{tabular}{llll}
\hline \hline Test No. & $\begin{array}{l}\text { Entrainment } \\
\text { coefficient }\end{array}$ & ds1 in Flow3D (m) & $\begin{array}{l}\text { ds1 in Experimental } \\
\text { model (m) }\end{array}$ \\
\hline \hline E1 & 0.018 & 0.0341 & 0.156 \\
E1 & 0.027 & 0.095 & 0.156 \\
E1 & 0.036 & 0.101 & 0.156 \\
E1 & 0.045 & 0.101 & 0.156 \\
\hline \hline
\end{tabular}

\section{Initial and Boundary conditions:}

15 At the inlet of the channel, the boundary is volume flow rate (Figure 2). Here, according to experimental conditions, volume flow rate was used with a constant discharge of 0.035 and 0.046 cubic meters per second and the entrance flow depth was $0.5 \mathrm{~m}$ from the channel bottom. On the sides (walls) and the bottom of the channel, the boundary conditions was set to be walls. To estimate the effect of the walls on flow, a well-known empirical equation for the standard wall function is used (Olsen, 2009):

$\frac{U}{u_{x}}=\frac{1}{k} \ln \left(\frac{30 h}{k_{s}}\right)$

20 Where $k_{s}=$ bed roughness, $k=$ Prandtl constant and equals 0.4 and $h=$ distance from the wall.

Symmetry boundary was used at the upper and inner boundaries as well. Continuative considered at downstream boundary.

All the applied boundary conditions have shown In Figure 2. 
Drink. Water Eng. Sci. Discuss., https://doi.org/10.5194/dwes-2017-21

Manuscript under review for journal Drink. Water Eng. Sci.

Discussion started: 8 June 2017

(c) Author(s) 2017. CC BY 3.0 License.

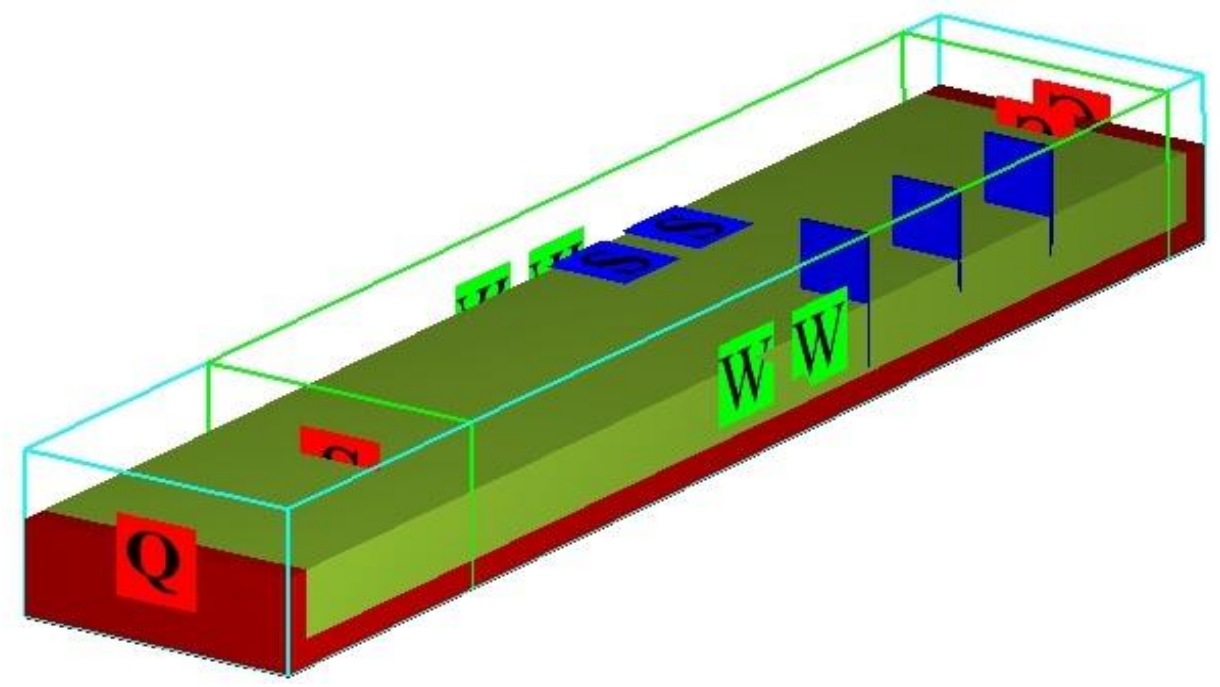

Figure 2: boundary conditions of FLOW-3D model

For initial condition, a fluid region in a sediment box technique was used with two aims, the first sediment should be saturated and second, sediment should not erode suddenly and wash from the channel due to the channel flow. The dimensions of the area that encompasses the entire sediment are 4.8 meters length, 1 meter wide and 35centimeters depth.

\section{Model Dimensions}

One of the usual problems that arise in such modeling is scouring at channel entry. If coarse mesh is used due to the rigid layer changes to sediment substrate, the erosion would become so much and could affect the flow which reaches to spur dikes. Even in some cases one can observe that the erosion of this part causes sedimentation in the scour hole near the first dike. To prevent this hazard, the model should start as far from spur dikes as possible at upstream channel. As another solution, sediment with more solid material can be used at the first of channel (With the same grain size but higher critical Shields number).Considering that the changing channel dimensions seem more reasonable and that the length should not be too short and also it should not be too long to minimize computing costs, some models with different length examined. The channel's length was chosen 5 meters. From the beginning of the channel till the first dike, the flow would become fully

15 developed and then the vortices would start. 
Drink. Water Eng. Sci. Discuss., https://doi.org/10.5194/dwes-2017-21

Manuscript under review for journal Drink. Water Eng. Sci.

Discussion started: 8 June 2017

(c) Author(s) 2017. CC BY 3.0 License.

(c) $\underset{\mathrm{BY}}{(i)}$

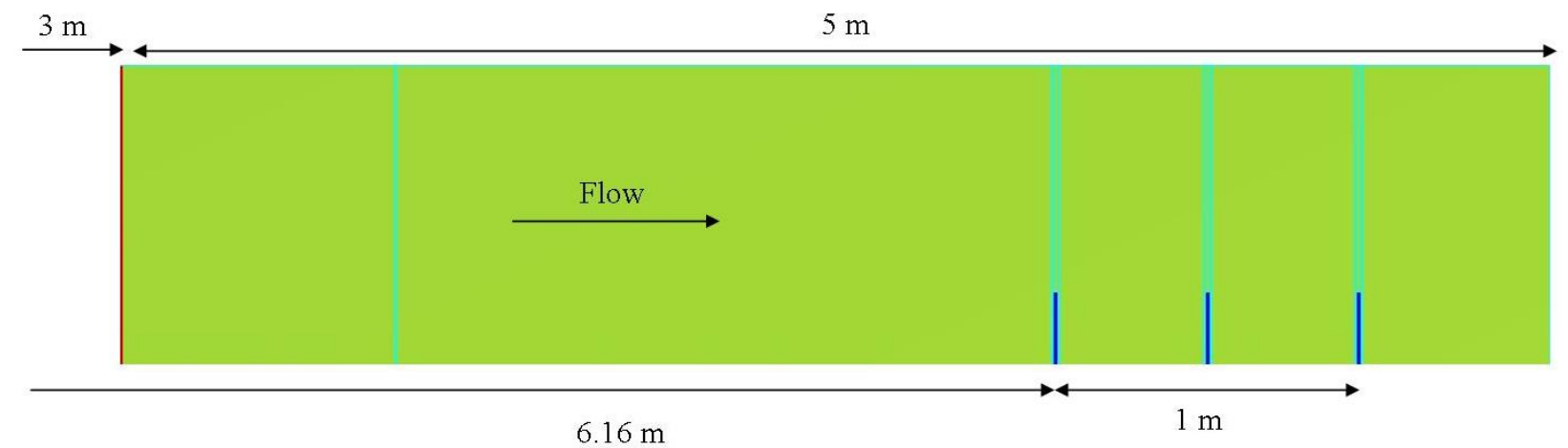

Figure 3: The numerical model of series of parallel spur dikes in FLOW-3D

\section{Mesh Dimensions}

Various models were tested in order to choose a suitable mesh. Nested mesh would lead to good modelling of vortices and

also it is matches the experimental data. According to the performed sensitivity mesh analysis, (table 3 ) and comparing the scour around the first spur dike with experimental results, two different mesh sizes were used at close distances to spur dikes. It should be noted that in presence of nested mesh, the internal and external mesh should not have a large difference in size. Empirically and in order to reduce errors, it is recommended that the ratio of two meshes set to be about 2.Also, at the intersections of the two meshes, it should be considered that mesh size should have gradual changes.

Table 2: Mesh Sensitivity analysis

\begin{tabular}{lllllll}
\hline \hline Test NO. & $\begin{array}{lllll}\text { Internal } \\
\text { mesh }(\mathbf{c m})\end{array}$ & $\begin{array}{l}\text { External } \\
\text { mesh }(\mathbf{c m})\end{array}$ & $\begin{array}{l}\text { Total } \\
\text { number of } \\
\text { cells }\end{array}$ & $\begin{array}{l}\text { Max Aspect } \\
\text { ratio }\end{array}$ & $\begin{array}{l}\text { ds1 in } \\
\text { Flow3D (m) }\end{array}$ & $\begin{array}{l}\text { ds1 in } \\
\text { Experimental } \\
\text { model (m) }\end{array}$ \\
\hline \hline E1 & 3 & 2 & 395880 & 1.9 & 0.099 & 0.156 \\
E1 & 2.5 & 1.2 & 1507550 & 1.7 & 0.133 & 0.156 \\
\hline
\end{tabular}

The dimension of the larger mesh is 2.5 centimeters with a count of $192000 .$. Smaller mesh size is 1.2 centimeters with a count of 1315550. In general, 1507550 mesh elements were utilized to model the channel (Figure 4). 
Drink. Water Eng. Sci. Discuss., https://doi.org/10.5194/dwes-2017-21

Manuscript under review for journal Drink. Water Eng. Sci.

Discussion started: 8 June 2017

(c) Author(s) 2017. CC BY 3.0 License.

(c) $\underset{\mathrm{BY}}{(i)}$
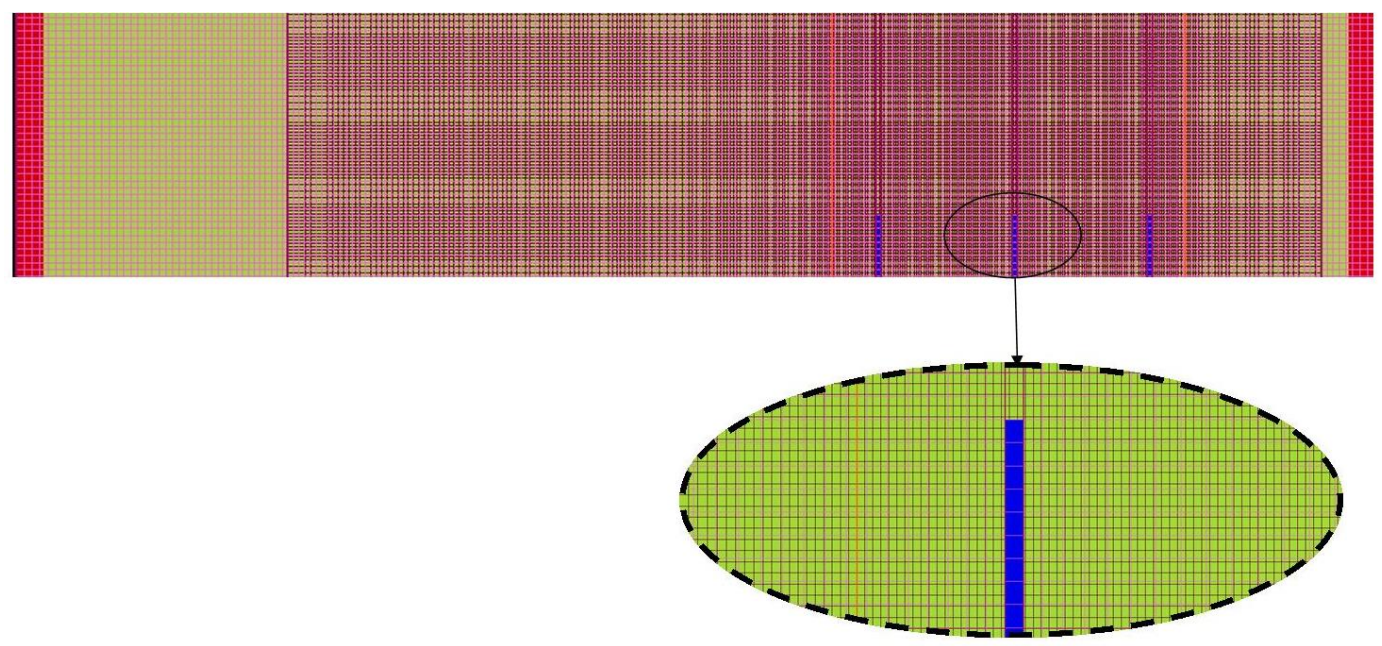

Figure 4: View of the meshed model in FLOW-3D

\section{Results of numerical model}

Numerical FLOW-3D modeling was performed for two different discharges. According to the results which are shown in

5 Figure 5, maximum scour is 0.133 meters in E1 and 0.182 in theE2 (E1 and E2 are test layouts). As it can be observed in figure 6, scour at the bottom of the first to third spur dike in test E1 is $0.123,0.005$ and 0.023 meter, respectively. Also it is seen in figure 7 that vortex flow is formed behind the second and third spur dikes and turbulent flow in the first spur dike is formed as well. Thus scour depth is increased at the bottom of the first spur dike.

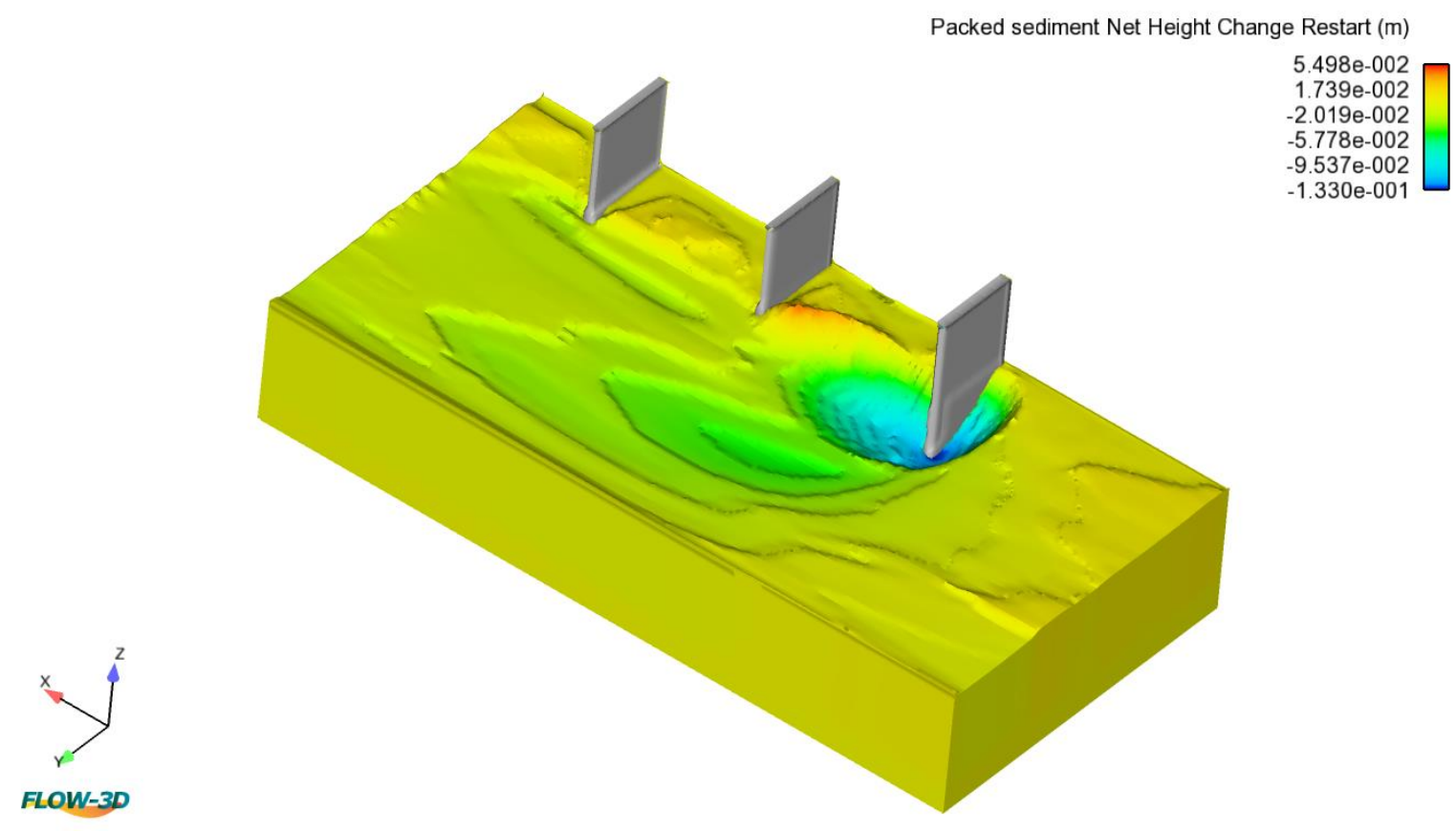


Drink. Water Eng. Sci. Discuss., https://doi.org/10.5194/dwes-2017-21

Manuscript under review for journal Drink. Water Eng. Sci.

Discussion started: 8 June 2017

(c) Author(s) 2017. CC BY 3.0 License.

Figure 5: Numerical modeling results of bed deformation in E1 test, Flow direction: Right to left

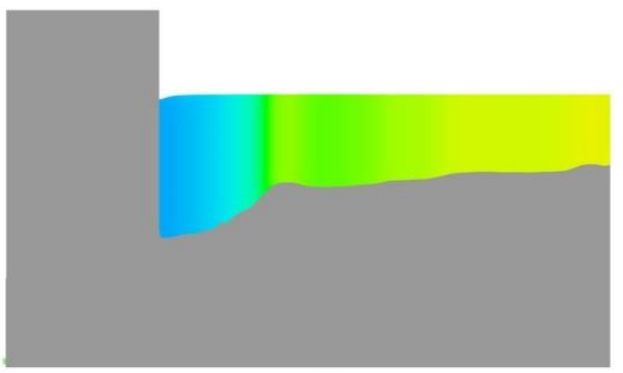

(a)

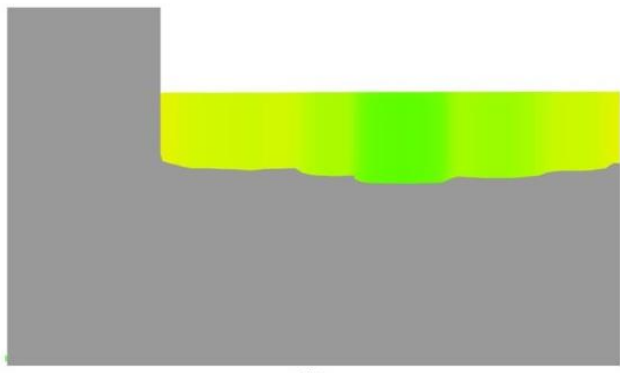

(b)
Packed sediment Net Height Change Restart (m)

$5.498 \mathrm{e}-002$

$1.739 \mathrm{e}-002$

$-2.019 \mathrm{e}-002$

$-5.778 \mathrm{e}-002$

$-9.537 \mathrm{e}-002$

$-1.330 \mathrm{e}-001$

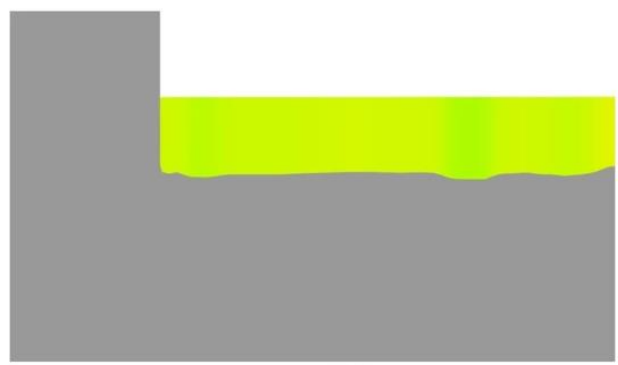

(c)

Figure 6: Scour at bottom of the spur dikes in E1 test (a) first spur dike (b) second spur dike (c) third spur dike in FLOW-3D

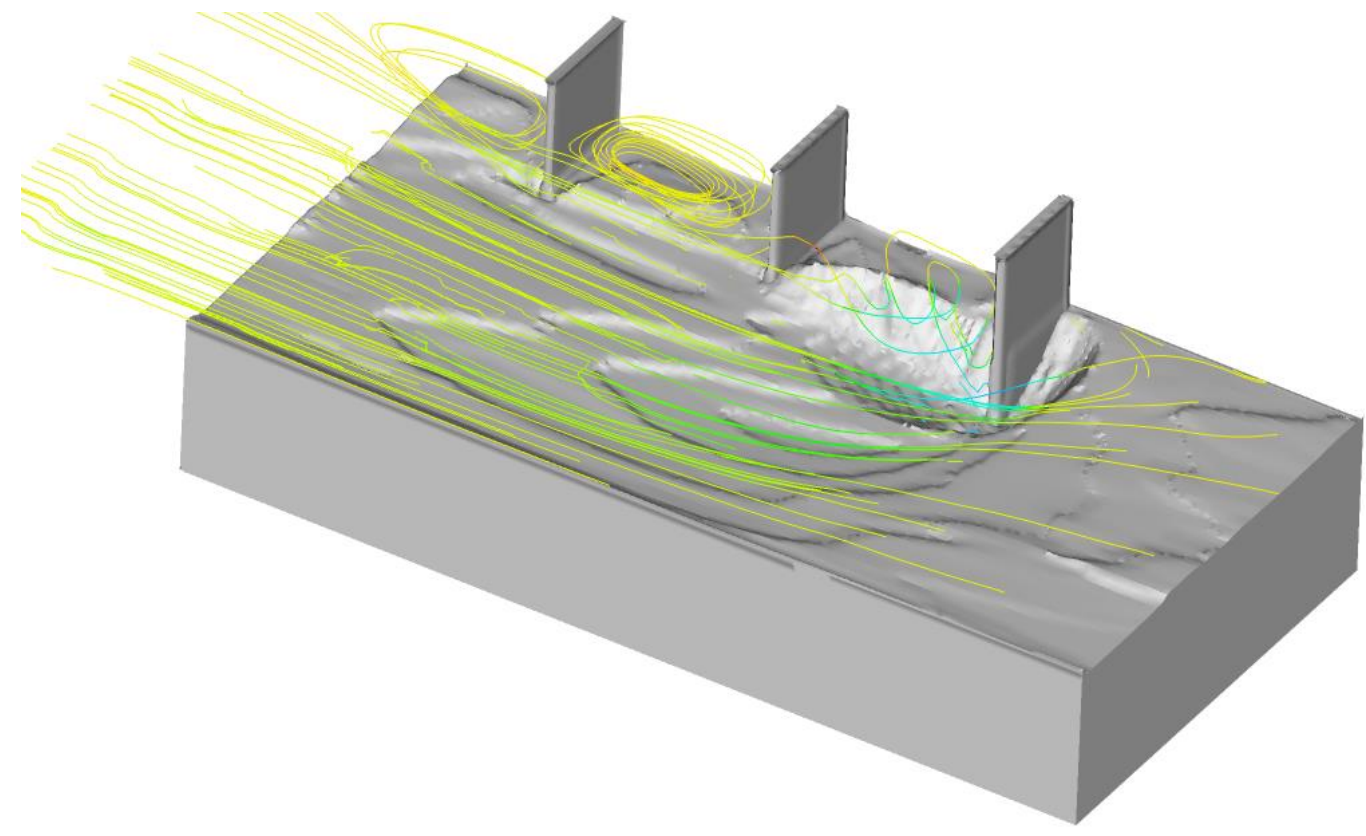

Figure 7: The flow vortices in vicinity of the spur dikes in E1 test 
Drink. Water Eng. Sci. Discuss., https://doi.org/10.5194/dwes-2017-21

Manuscript under review for journal Drink. Water Eng. Sci.

Discussion started: 8 June 2017

(c) Author(s) 2017. CC BY 3.0 License.

(c) (i)

\section{Conclusions}

The parameters $\mathrm{R}^{2}$, MAE, and RMSE were compared for the results of FLOW-3D and SSIIM to test the data matching with experimental data (Karami et al. 2014), the mentioned parameters have been expressed respectively in equations (10), (11) and (12).

$R^{2}=1-\frac{\sum_{i=1}^{n}\left(E_{i}-N_{i}\right)^{2}}{\sum_{i=1}^{n}\left(E_{i}-\bar{E}_{i}\right)^{2}}$

$M A E=\frac{1}{n} \sum_{i-1}^{n}\left|E_{i}-N_{i}\right|$

$R M S E=\sqrt{\frac{1}{n} \sum_{i=1}^{n}\left(E_{i}-N_{i}\right)^{2}}$

5 Where $E_{i}$ are experimental results, $N_{i}$ are numerical results and $\mathrm{n}$ are number of data.

\section{Comparison of time modeling}

Scour time is an important parameter in numerical simulations. After a few initial tests, it was observed that the greatest depth and associated time with scouring depth, around the first spur dike are more critical than others. Afterward, maximum scourdepth dike was taken into account as the balance considerations of erosion in numerical modeling. Equilibrium basis

10 was considered as depth changes that are less than $1 \mathrm{~mm}$ in 100 seconds. The results showed that the E1 model in 1350 seconds and E2 model in 1600 seconds reach equilibrium. As seen in Figure 8, the equilibrium time results ofthe numericalmodel were compared with experimental results and for theE1 test, $\mathrm{R}^{2}, 0.95$ and for theE2 test, $\mathrm{R}^{2}, 0.98$ were calculated which demonstrates the consistency of the experimental and numerical data. It should be mentioned that laboratory equilibrium time was considered as depth change which was less than $1 \mathrm{~mm}$ at the time of 8 hours by (Chiew,

15 1992).Figure 8 parameters are, scour time $(t)$, maximum scour depth at the time $(t),\left(d_{\text {st }}\right)$, equilibrium scour depth $\left(d_{s e}\right)$, and the time to reach equilibrium depth $(\mathrm{T})$. 
Drink. Water Eng. Sci. Discuss., https://doi.org/10.5194/dwes-2017-21

Manuscript under review for journal Drink. Water Eng. Sci.

Discussion started: 8 June 2017

(c) Author(s) 2017. CC BY 3.0 License.
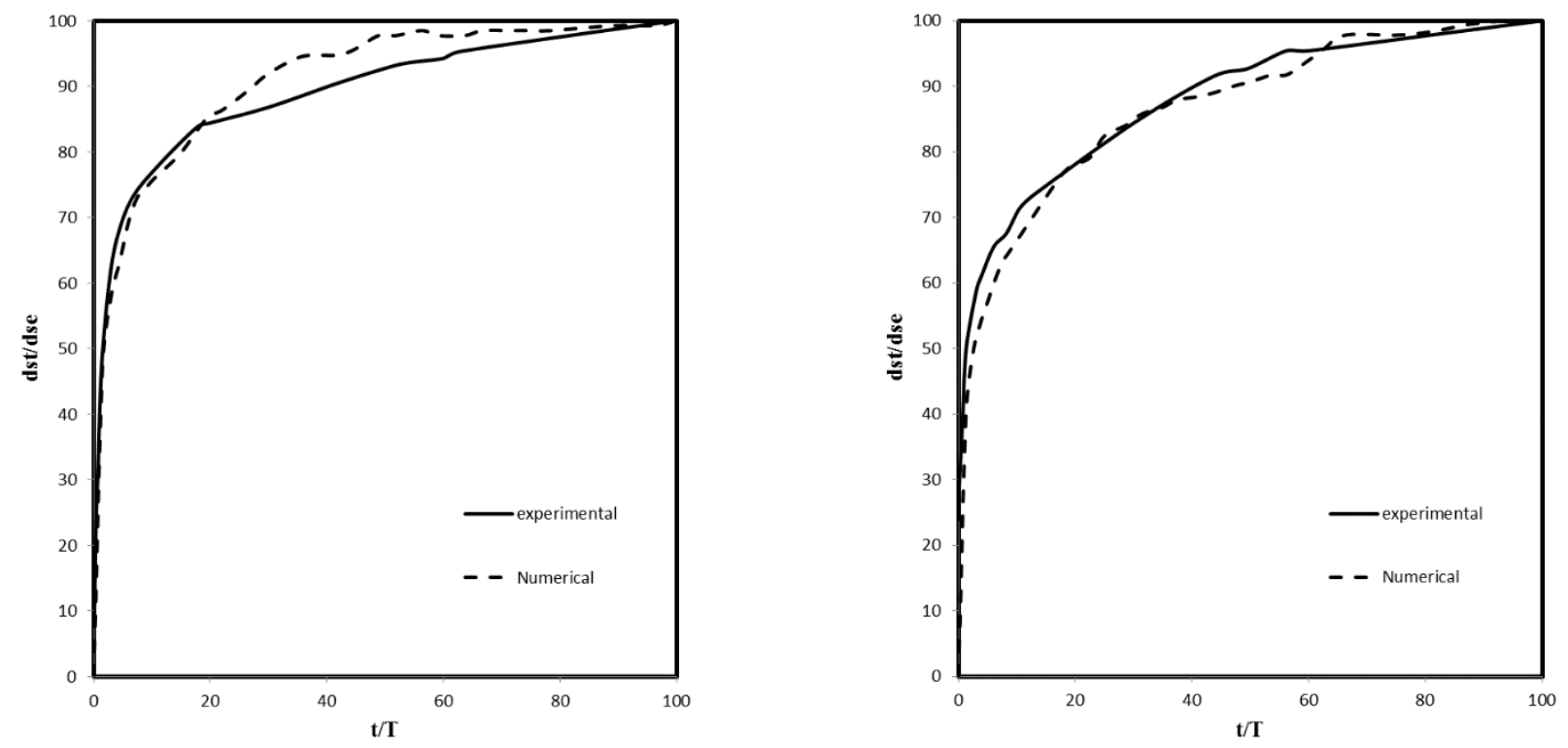

Figure 8: Dimensionless graph of equilibrium time of scouring in (a: Left) E1 test and (b: Right) E2 test in FLOW-3D

\section{Hydraulic comparisons (SSIIM, Flow3D, Experimental)}

With the aim of calibration of CFD flow simulation model results, and the experimental results used in this way that the speed of 50 points in $\mathrm{Z}$ (level), equal to $2 \mathrm{~cm}$ above the bed, measured in theE2 test for properties. These speeds are at the distances 5.56, 59.5, 6.16, 6.41 and 6.66 meters, which are shown in Figure 9.The results showed that $\mathrm{k}-\varepsilon$ turbulence model with some RNG extensions indicates the most concordance like software SSIIM (Karami et al. 2014) with experimental results. Figure 9 shows the absolute simulated speed comparison between two software, FLOW-3D, and SSIIM and absolute measured speed. From this figure, it can be concluded that the CFD model simulated the flow with sufficient accuracy. Also, quantitative comparisons results showed that FLOW-3D software with $\mathrm{R}^{2}, 0.89$ and SSIIM software with $\mathrm{R}^{2}, 0.94$, has the capability for hydraulic flow simulation and there is not much difference between them. 
Drink. Water Eng. Sci. Discuss., https://doi.org/10.5194/dwes-2017-21

Manuscript under review for journal Drink. Water Eng. Sci.

Discussion started: 8 June 2017

(c) Author(s) 2017. CC BY 3.0 License.
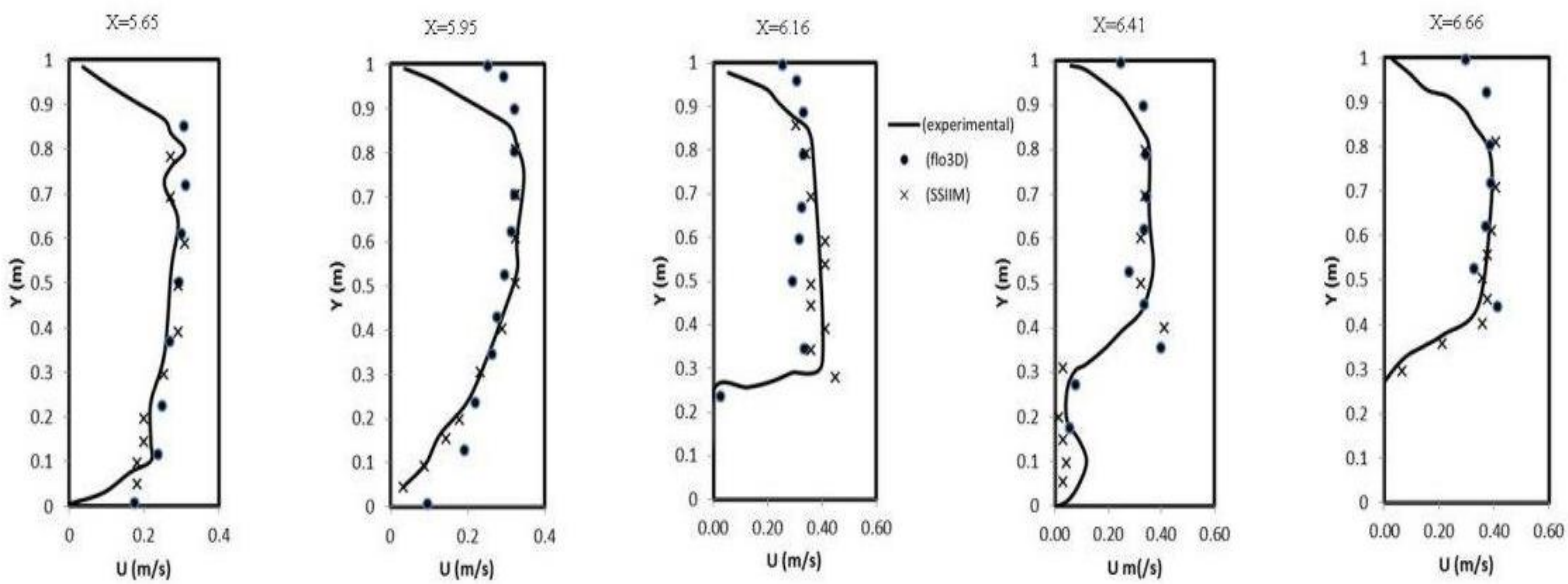

Figure 9: CFD model comparison with experimental results

\section{Sediment comparisons}

In this study, the final results of FLOW-3D numerical model results were compared with experimental results and the SSIIM

model results. Results showed that due to the sub-critical flow, secondary flow strength and vortices from the beginning of the first spur dike appears and morphological contract changes gradually. Considering that the contraction in both tests is less than the maximum contraction and specific energy in contraction is larger than minimum specific energy. Flow depth reduces a little in contraction and flows regime does not change. The results of both software and experimental results also confirm this situation. With the aim of quantitative investigation of the bed changes result, experimental and software result were compared in transverse and longitudinal sections. Two cross-sectional and longitudinal sections selected in parts after contraction and in total, scouring in 80 points, in E1 and E2 tests as shown in Figure 10 and Figure 11, were examined. In Table 4 scour depth in this 80 points in each test were compared with experimental results. Scour depth inthe bottom of the first to third spur dikes also mentioned in this table. The results show that, in theE1 test, theFLOW-3D model is more accurate than SSIIM model while in test E2, FLOW-3D model accuracy is very low and unacceptable. It seems that this huge difference is due to the variations in $\mathrm{U} / \mathrm{U}_{\mathrm{cr}}$. So that, FLOW-3D model calibrated in Test 1 for $\mathrm{U} / \mathrm{U}_{\text {cr }}$ equals to 0.65 and if this value changes, considering its importance, re-calibration of the model required. As a result, calibrated model of FLOW-3D software can be used just at the same discharge. 
Drink. Water Eng. Sci. Discuss., https://doi.org/10.5194/dwes-2017-21

Manuscript under review for journal Drink. Water Eng. Sci.

Discussion started: 8 June 2017

(c) Author(s) 2017. CC BY 3.0 License.

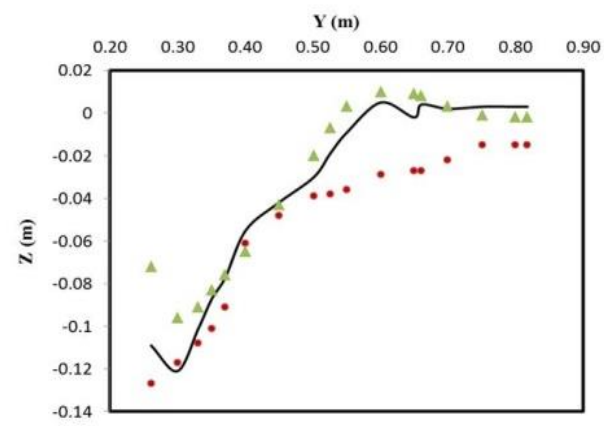

(a)

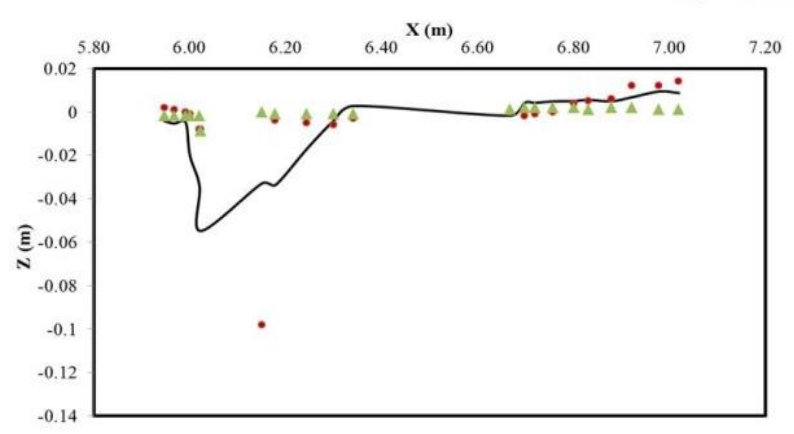

(c)

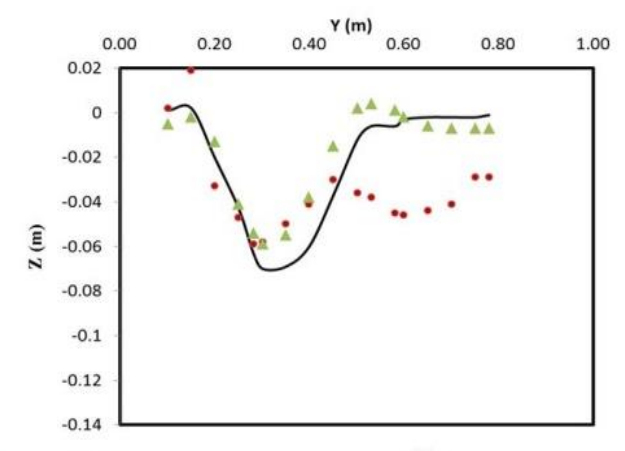

(b)

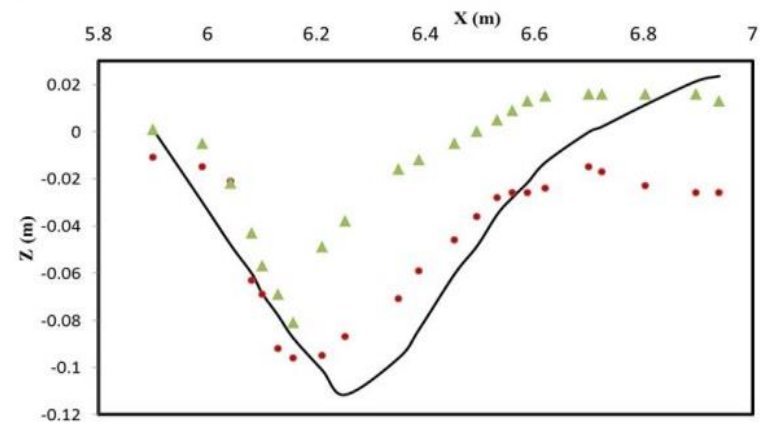

(d)

Figure 10: Bed changes comparison of the FLOW-3D results in E1 test with SSIIM and experimental results

(a) $X=6.16$ (b) $X=6.41$ (c) $Y=0.15$ (d) $Y=0.35$

Table 4: Comparison of the scouring amount in FLOW-3D model with SSIIM model and experimental data

\begin{tabular}{ll|llllll}
\hline \hline Test & & ds1 & ds2 & ds3 & MAE & RMSE & $\mathbf{R}^{2}$ \\
\hline \multirow{3}{*}{ E1 } & Experimental & 0.156 & 0 & 0.026 & - & - & - \\
& Flow3D & 0.123 & 0.005 & 0.023 & 0.0162 & 0.0214 & 0.6416 \\
& SSIIM & 0.101 & 0.033 & 0.013 & 0.0151 & 0.0233 & 0.5754 \\
\hline \multirow{2}{*}{ E2 } & Experimental & 0.225 & 0.029 & 0.072 & - & - & - \\
& Flow3D & 0.1785 & 0.0177 & 0.0321 & 0.0503 & 0.06596 & 0.1599 \\
& SSIIM & 0.2122 & 0.033 & 0.066 & 0.0424 & 0.0546 & 0.4240 \\
\hline \hline
\end{tabular}


Drink. Water Eng. Sci. Discuss., https://doi.org/10.5194/dwes-2017-21

Manuscript under review for journal Drink. Water Eng. Sci.

Discussion started: 8 June 2017

(c) Author(s) 2017. CC BY 3.0 License.

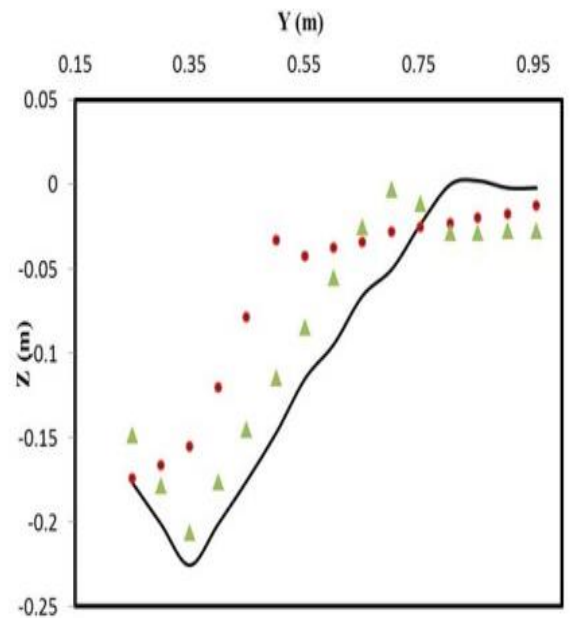

(a)

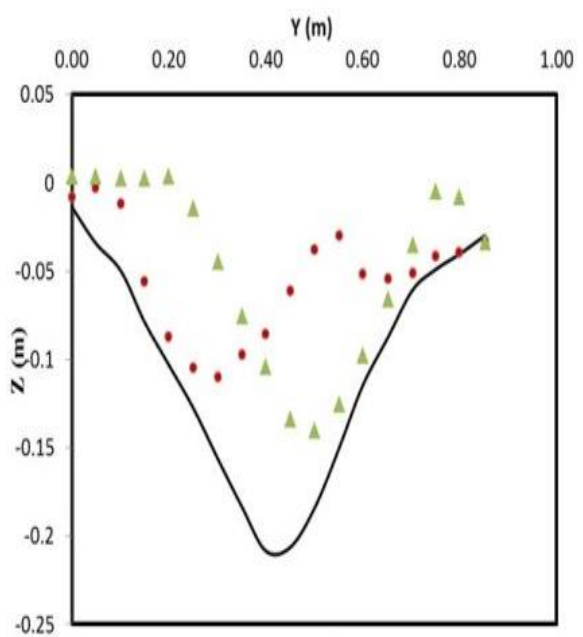

(b)

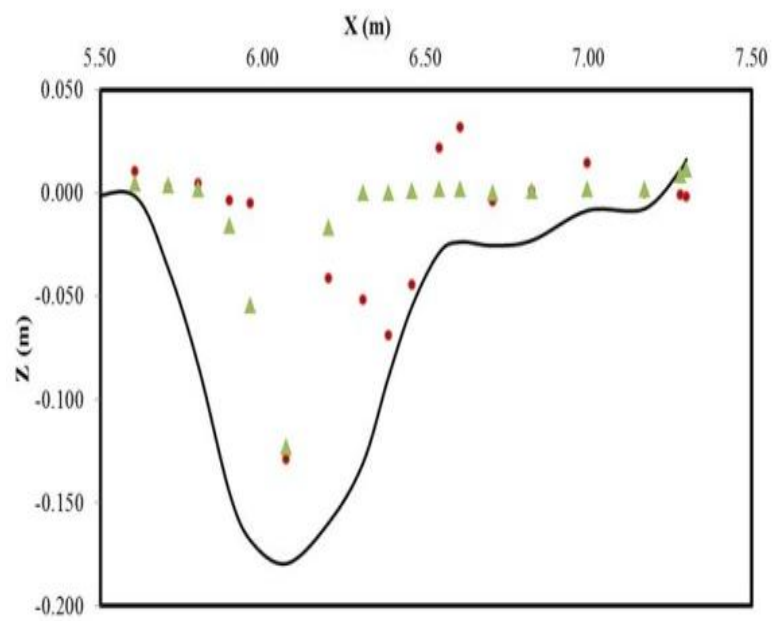

(c)
FLOW3D A SSIIM

$500-5700-5900-6100-630050500$

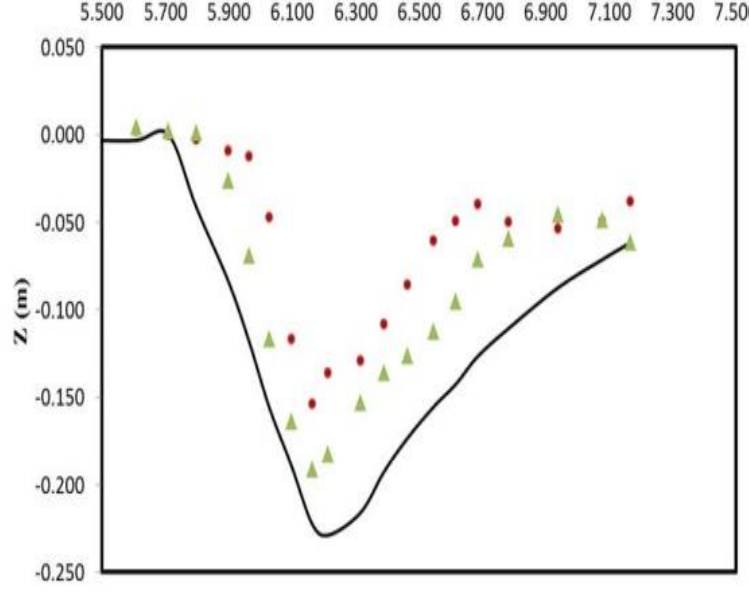

(d)

Figure 11: Bed changes comparison of the FLOW-3D results in E2 test with SSIIM and experimental results

(a) $X=6.16$ (b) $X=6.41$ (c) $Y=0.15$ (d) $Y=0.35$

\section{Summary and Conclusions}

5 In this study, the accuracy of the FLOW-3D software versus SSIIM software (Karami et al., 2014) was evaluated by comparing their model results with experimental data. To do this, the research conducted by (Karami et al., 2014) was used, which was performed experimentally and numerically. Van Rijn sediment model is also examined, which recently added to the FLOW-3D Model. 
Drink. Water Eng. Sci. Discuss., https://doi.org/10.5194/dwes-2017-21

Manuscript under review for journal Drink. Water Eng. Sci.

Discussion started: 8 June 2017

(c) Author(s) 2017. CC BY 3.0 License.

(c) (i)

The results showed that Froude number and $\mathrm{U} / \mathrm{U}_{\mathrm{cr}}$ ratio affect the accuracy of the models. Thus, with discharge increase, models need to be re-calibrated. Also, by using a calibrated FLOW-3D model calculation accuracy of the scour depth at the bottom of the spur dikes will be better and accuracy in the modelling of the surface morphology improves more than SSIIM software (Karami et al., 2014), scour at the bottom of the first, second and third spur dike, 7, 80 and 40 percent improves.

5 The difference in calibrated and the model which need re-calibration FLOW-3D software could be due to the calculations of boundary conditions or time destruction in solving differential equations by finite volume method.

\section{References}

Kuhnle, R. A., Alonso, C. V., \& Shields Jr, F. D. (2002), Local scour associated with angled spur dikes. Journal of Hydraulic Engineering, 128(12), 1087-1093.

10 Klingeman, P. C., Kehe, S. M., \& Owusu, Y. A. (1984), Stream bank erosion protection and channel scour manipulation using rock fill dikes and gabions.

Ahmad, M. (1951), Spacing and protection of spurs for bank protection, Civil Engineering and Publication Review, 46, 3-7.

Ahmad, M. (1953), Experiments on design and behaviour of spur dikes. In Proceedings: Minnesota International Hydraulic Convention (pp. 145-159). ASCE.

15 Garde, R., Subramanya, K., \& Nambudripad, K. D. (1961), Study of scour around spurdikes. Journal of the Hydraulics Division, 86, 23-37.

Gill, M. A. (1972), Erosion of sand beds around spur dikes, Journal of the Hydraulics Division, 98(hy9).

Richardson, E. V., Stevens, M. A., \& Simons, D. B. (1975), the design of spurs for river training, In Proceeding of the 15th Congress of the International Association for Hydraulic Research, IAHR, Basil (Vol. 2, pp. 382-388).

20 Rajaratnam, N., \& Nwachukwu, B. A. (1983), Erosion near groyne-like structures, Journal of hydraulic Research, 21(4), 277-287.

Shields Jr, F. D., Cooper, C. M., \& Knight, S. S. (1995), Experiment in stream restoration. Journal of Hydraulic Engineering, 121(6), 494-502.

Kuhnle, R. A., Alonso, C. V., \& Shields, F. D. (1999), The geometry of scour holes associated with 90 spur dikes. Journal of 25 Hydraulic Engineering, 125(9), 972-978.

Kothyari, U. C., \& RangaRaju, K. G. (2001), Scour around spur dikes and bridge abutments. Journal of hydraulic research, 39(4), 367-374.

Barbhuiya, A. K., \& Dey, S. (2004). Local scour at abutments: A review. Sadhana, 29(5), 449-476. 
Drink. Water Eng. Sci. Discuss., https://doi.org/10.5194/dwes-2017-21

Manuscript under review for journal Drink. Water Eng. Sci.

Discussion started: 8 June 2017

(c) Author(s) 2017. CC BY 3.0 License.

Kang, J., Yeo, H., Kim, S., \& Ji, U. (2011). Experimental investigation on the local scours characteristics around groynes using a hydraulic model. Water and Environment Journal, 25(2), 181-191.

Chang, Y. L., Hsieh, T. Y., Chen, C. H., \& Yang, J. C. (2013), Two-Dimensional Numerical Investigation for Short-and Long-Term Effects of Spur Dikes on Weighted Usable Area of Rhinogobius candidianus (Goby), Journal of Hydraulic

5 Engineering, 139(12), 1297-1303.

Karami, H., Basser, H., Ardeshir, A., \& Hosseini, S. H. (2014), Verification of numerical study of scour around spur dikes using experimental data. Water and Environment Journal, 28(1), 124-134.

Mendoza-Cabrales, C. (1993). Computation of flow past a cylinder mounted on a flat plate. In Hydraulic Engineering (pp. 899-904), ASCE.

10 Acharya, A., \&Duan, J. G. (2013), Three-dimensional simulation of the flow field around series of spur dikes. International Refereed Journal of Engineering and Science (IRJES), 2, 36-57.

Duan, J. G., \& Nanda, S. K. (2006), Two-dimensional depth-averaged model simulation of suspended sediment concentration distribution in a groyne field, Journal of Hydrology, 327(3), 426-437.

Kuhnle, R. A., Jia, Y., \& Alonso, C. V. (2008), Measured and simulated flow near a submerged spur dike. Journal of

15 Hydraulic Engineering, 134(7), 916-924.

An, S., Ku, H., \& Julien, P. Y. (2015), Numerical modeling of local scour caused by submerged jets, Maejo International Journal of Science and Technology, 9(3), 328.

Li, D., Shi, B., Wu, G., \& Liang, B. (2016), Numerical Simulation of Near shore Submarine Pipeline Scour under Storm Surge Condition, In The 26th International Ocean and Polar Engineering Conference. International Society of Offshore and

20 Polar Engineers.

Shamohamadi, B., \& Mahboodi, A. (2016), Analyzing Parameters Influencing Scour Bed in Confluence Channels Using Flow3D Numerical Model. Civil Engineering Journal, 2(10), 529-537.

Van Rijn, L. C. (1987). Mathematical modeling of morphological processes in the case of suspended sediment transport (pp. Communication-No). Delft: Water loopkundig Laboratorium

25 Mastbergen, D. R., \& Van Den Berg, J. H. (2003), Breaching in fine sands and the generation of sustained turbidity currents in submarine canyons, Sedimentology, 50(4), 625-637.

Olsen, N. R. B. (2009), a three-dimensional numerical model for simulation of sediment movements in water intakes with a multiblock option. Department of Hydraulic and Environmental Engineering: the Norwegian University of Science and Technology.

30 Chiew, Y. M. (1992). Scour protection at bridge piers, Journal of Hydraulic Engineering, 118(9), 1260-1269 